\title{
Preface: Making more than a dent in poverty
}

Developed economies have produced impressive levels of income, wealth, and overall quality of life for their citizens, not only in comparison to most developing countries, but also relative to historical standards. Yet, a sizeable proportion of the populations of these countries remain in poverty. Despite many billions of dollars of expenditures since the 1964 launch of the "War on Poverty" in the United States, the poverty rate remains close to 14 percent - largely where it was 50 years ago. In the European Union, 23.5 percent of the population are at risk of poverty or social exclusion (Eurostat Newsrelease, 2017). And the disparity between rich and poor continues to grow, suggesting a problem in both absolute and relative levels of poverty.

While some might argue there will always be poor people, their sheer numbers, and the corresponding cost both to those who must live in poverty conditions and the larger society, is simply unacceptable. Poverty is not just about a lack of income or wealth, it is a complex and multidimensional phenomenon. It affects and is affected by an array of issues, including housing, education, health, transportation, family relationships, personal safety, job opportunities, career prospects, and psychological and emotional well-being. The barriers that it imposes become all the more formidable as societies become more technology-centric, labor-intensive jobs disappear, and economies continue to transform.

So what can be done? Perhaps we just need to spend more money on housing, food, education, and other support programs. Maybe the need is to spend the money differently, with a more integrated (and perhaps creative) approach that reflects unique needs of poor people in differing circumstances. There are those who would simply let the poor fend for themselves, believing they just have to apply themselves, work hard, and persevere and things will work out. Others staunchly argue for forced income redistribution from the haves to the have-nots, so as to guarantee some sort of living wage. Without getting into the political discussions that surround such diverse positions, this book proposes another possibility: entrepreneurship. 
In these chapters, we explore venture creation as a pathway out of poverty. While considerable attention has been devoted to entrepreneurship as a solution to poverty in developing countries (e.g., Amorós and Cristi, 2011; Bruton, Ketchen and Ireland, 2013; McMullen, 2011; Webb et al., 2013), its role within developed economies has received much less focus. Yet, we believe its potential is as great or greater in developed economies, where infrastructure exists, market opportunities can be significant, and entrepreneurship is an established vehicle for achieving economic success.

Entrepreneurship is ultimately about empowerment and transformation. It is about creating one's own future, job, income, wealth, identity, sense of purpose, and ability to give back. It transforms markets, industries, communities, families and individual entrepreneurs. In the final analysis, entrepreneurship involves a mindset, a way of approaching life and the world. It is a willingness to pursue opportunity regardless of the few resources a poor person owns or controls (Stevenson, 1983).

In these pages, we will argue that entrepreneurship is a natural inclination of the poor. As Muhammad Yunus (2005) has concluded, "the poor themselves can create a poverty-free world. All we have to do is to free them from the chains that we have put around them." As we shall see in these pages, these chains are powerful, but they can be broken. Entrepreneurship is not something that is new among the poor. There have always been people who start ventures out of conditions of poverty. In fact, it is amazing how many successful ventures have been created by the poor given the complex burdens that come with poverty and the inherent difficulties in starting a business. The question becomes, what might be possible if the poor had more help?

Entrepreneurship has never been a major policy focus when it comes to poverty. There are relatively few people who believe, or have suggested, that it could fundamentally change the overall poverty landscape. However, this is our position in this book. The challenge is to level the playing field when it comes to venture creation by the poor. It is unlikely the field could ever be completely levelled, as the poor will always have a greater struggle than those with higher income, better education, more extensive networks, fewer health problems, safer surroundings, and more exposure to entrepreneurial ventures, mentors, and role models. But to paraphrase Steve Jobs, we can do much more than simply make a dent in the poverty universe.

In the chapters to come, we first lay out the nature and extent of the poverty problem in developed economies, followed by a discussion of the nature of entrepreneurship and venture creation, and this is followed by an exploration of the challenges and opportunities in connecting the two. We introduce the SPODER framework as a simple model for understanding what is required for the low-income individual to successfully pursue the 
entrepreneurial path, and the kinds of issues that must be navigated during the entrepreneurial journey. What is known about types of entrepreneurs and types of ventures are then applied to the entrepreneurial efforts of the poor, with insights on why the poor disproportionately create survival and marginal lifestyle-type ventures. The critical role of opportunity recognition is examined, together with ways to expand the opportunity horizons of those in poverty. We next dedicate chapters to exploring the challenges of literacy, technology, and community infrastructure (including entrepreneurial ecosystems) as each relates to a person in poverty when trying to launch a business. Attention is devoted to financing needs and options when one has little income, lacks collateral, and may have no credit history or a low credit score. The central roles of leveraging, bootstrapping, and guerrilla skills in obtaining or accessing resources are then investigated. The tendency of the ventures created by the poor to fall into the "commodity trap," and how this can be overcome, are both reviewed, and ways to improve the underlying profit models of these ventures are identified. Finally, we look at the need for a holistic approach to developing both public policy and community-based initiatives that facilitate low-income entrepreneurs as they prepare for, launch, and grow successful ventures.

The reality is that entrepreneurship in its many forms offers promise to everyone in poverty. This is a promise of self-empowerment enabled by community support for a sector of society that is incredibly rich in entrepreneurial potential. It is a promise not being realized in our most prosperous nations. Our hope is that this book fosters a richer dialog among academics, government officials, policy-makers, economic development professionals, bankers and the financial community, leaders of non-profit organizations, and others committed to moving beyond status quo solutions - committed to finding ways to help people create their own entrepreneurial pathways out of poverty.

Michael H. Morris
Susana C. Santos
Xaver Neumeyer

\section{REFERENCES}

Amorós, J.E. and O. Cristi (2011), "Poverty and entrepreneurship in developing countries," in M. Minniti (ed.), The Dynamics of Entrepreneurship: Evidence from Global Entrepreneurship Monitor Data, Oxford Scholarship Online, pp. 209-30.

Bruton, G.D., D.J. Ketchen Jr. and R.D. Ireland (2013), "Entrepreneurship as a solution to poverty," Journal of Business Venturing, 28(6), 683-9.

Eurostat Newsrelease (2017), 'Downward trend in the share of persons at risk 
of poverty or social exclusion in the EU', October 16, accessed June 6, 2018 at http://ec.europa.eu/eurostat/documents/2995521/8314163/3-16102017-BP-EN.pd f/d31fadc6-a284-47f3-ae1c-8212a581b0c1.

McMullen, J.S. (2011), "Delineating the domain of development entrepreneurship: A market-based approach to facilitating inclusive economic growth," Entrepreneurship Theory and Practice, 35(1), 185-93.

Stevenson, H.H. (1983), A Perspective on Entrepreneurship (Vol. 13), Cambridge, MA: Harvard Business School Press.

Webb, J.W., G.D. Bruton, L. Tihanyi and R.D. Ireland (2013), "Research on entrepreneurship in the informal economy: Framing a research agenda," Journal of Business Venturing, 28(5), 598-614.

Yunus, M. (2005), "Eliminating poverty through market-based social entrepreneurship," Global Urban Development Magazine, 1(1), accessed June 6, 2018 at http:// www.globalurban.org/Issue1PIMag05/Yunus\%20article.htm. 